\title{
Production waste analysis using value stream mapping and waste assessment model in a handwritten batik industry
}

\author{
Putri Citra Marifa*, Feny Yuliana Andriani, Sri Indrawati, Anggita Noviyanti Parmasari, Hardiyanti Budiman, and Atika \\ Kamilia
}

Industrial Engineering, Universitas Islam Indonesia, Yogyakarta, Indonesia

\begin{abstract}
Batik is one of Indonesian cultural heritage that confirmed by United Nations of Educational, Scientific, and Cultural Organization (UNESCO) on October 2009. This legal confirmation improves the number of batik industry from many regions based its local unique characteristic. The increasing number of batik SMEs in Indonesia requires a strategy that can create competitive advantage. This strategy can be done by reducing production waste. One of Indonesian batik SMEs is SME Batik CM located in Yogyakarta. There are several problems that occur in the industry, i.e. length of the production process, spots on Batik and excessive raw materials inventory. Based on that problems, this research is done by applying lean manufacturing concept using value stream mapping (VSM) method to evaluate production wastes. Based on the result of the research, there are seven types of production waste: overproduction $(9,62 \%)$, inventory $(17,3 \%)$, defect $(23,08 \%)$, motion $(9,62 \%)$, transportation $(9,62 \%)$, Over processing $(9,62 \%)$ and waiting $(21,15 \%)$. Process improvement is done to reduce the highest waste, defect, using quality filter mapping (QFM).
\end{abstract}

\section{Introduction}

The economic and trading development in recent years creates a tight business competition. All industries are forced to improve business competitive advantage [1]. Batik industry is one of industry that needs to improve the manufacturing and business process. Batik is one of Indonesian cultural heritage that confirmed by United Nations Educational, Scientific, and Cultural Organization (UNESCO) on October 2009. This legal confirmation improves the number of batik industry from many regions based its local unique characteristic. The number of batik industry in Indonesia is increasing from year to year as seen in Figure 1.

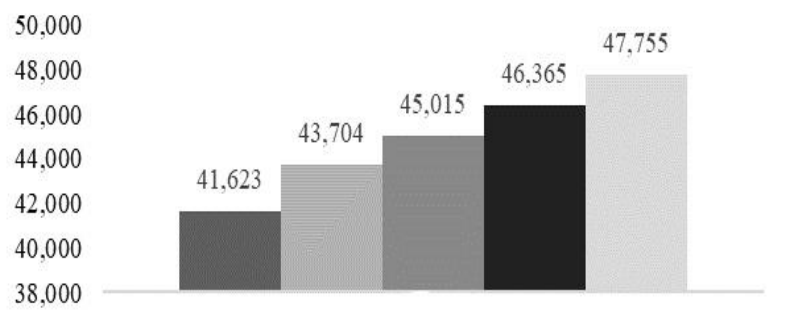

-2011 $=2012=2013 \backsim 2014=2015$

Figure 1. The development of batik industry in Indonesia [2]
One of batik industry in Indonesia is Batik CM that produces handwritten batik cloth with Javanese classic pattern. The process of making handwritten batik is different and takes longer time than stamped batik. It needs an accuracy so that Batik CM only produces 5 products per day. In the production process there are some steps such as pattern design, batik work, colouring, ngeblok, ngerok, mbironi, nglorot, giving starch, drying and packaging. There are several problems that occur in the industry, i.e. length of the production process, spots on Batik and excessive raw materials inventory. A production waste reduction is needed to improve the productivity of batik industry.

Production waste is any production activity that doesn't provide a value in processing input into output along value steam [3]. To reduce production wastes and cost, lean manufacturing can be implemented [4]. Production wastes are being eliminated through a systematic approach through lean manufacturing implementation [5]. Lean is a continual effort to reduce production wastes so that it can increase productivity and product quality [6].

Elimination of production waste can be effectively done using five criteria, i.e. process \& equipment enhancement (PEE), production rules \& discipline (PRD), Workforce Engagement (WFE), suppliers' integration (SUI) and customer focus (CUF) [7]. Most of research have reported that workforce development and total quality management (TQM) are commonly used on lean practices [8]. To achieve lean goals, a value stream mapping (VSM) is a powerful tool to evaluate the

\footnotetext{
* Corresponding author: $14522030 @$ students.uii.ac.id
} 
relationship of people, process, tools and information along the value sream [9]. VSM can help the industry to get better understanding of lean concepts and continuous improvement process [10].

\section{Basic Theory}

\subsection{Value Stream Mapping (VSM)}

VSM is a tools that can lead an industry to a better condition through continuous improvements, communication and process inefficiencies reduction [11]. Flows of information and materials of current production process is visually summarized and evaluated then envisioning a future state map with a better performance [12]. Process activity analysis is used in VSM to evaluate value added and non-value added activities. Value added activity is activity that add value to the product. Taiichi Ohno stated that non-value added activities should be eliminated [13].

\subsection{Value Stream Analysis Tool (VALSAT)}

Value Stream Analysis Tool (VALSAT) is used to analyse production waste and give recommendation to improve manufacturing performance. Based on Shigeo Shingo, there are seven wastes that can be identified in production [14]. The main function of VALSAT is to identify and evaluate production [15]. There are seven type of VALSAT tools, i.e. process activity mapping, supply chain response matrix, production variety funnel, quality filter mapping, demand amplification mapping and decision point analysis.

\section{Research Method}

This research is done through six main stages, i.e. production waste identification, production waste prioritization and production waste evaluation. Production waste identification is done by identifying all production activities. After knowing the activities in batik production process, then production waste analysis is done using VSM. Production waste prioritization is done through waste relationship matrix and waste assessment model. The purpose of this step is to know the biggest production waste that occurs. After knowing the biggest waste, then VALSAT is used to evaluate the waste in Batik CM Industry.

\section{Discussion}

\subsection{Value Stream Mapping (VSM)}

Based on current state map of VSM that describe production process in Batik CM, this industry value added activity is 9175 minutes and non value added activity 11547 minutes. There are product defect in handwritten batik production process. In batik work, there are 5\% product defect. From ngeblok process, the product defect rate is at $3 \%, 15 \%$ in ngerok process, $10 \%$ in bironi process, $2 \%$ in second coloring process and $2 \%$ in nglorot process.

\subsection{Waste Assessment Model}

A waste relationship matrix is develop to evaluate the correlation between production waste. This matrix is used to analyze the influence of a production waste to others. There are seven production waste in batik processing, i.e. overproduction (O), inventory (I), product defect (D), unnecessary motion (M), transportation (T), overprocessing $(\mathrm{P})$ and waiting time $(\mathrm{W})$ as seen in Table 1. The production waste that becomes the most influential to others is product defect at $23,08 \%$. It means that product defect give a big impact in causing another waste. Moreover, the most affected production waste is overproduction. It is shown with a highest score from WRM column, the overproduction score is at $17,31 \%$.

Table 1. Waste relationship matrix

\begin{tabular}{|c|c|c|c|c|c|c|c|c|c|}
\hline F/T & $\mathbf{0}$ & I & D & M & T & P & W & Score & \% \\
\hline O & 10 & & & & & & & 10 & 9,62 \\
\hline I & 2 & 10 & 2 & 2 & 2 & & & 18 & 17,31 \\
\hline D & 2 & 2 & 10 & 2 & 2 & 2 & 4 & 24 & 23,08 \\
\hline M & & & & 10 & & & & 10 & 9,62 \\
\hline T & & & & & 10 & & & 10 & 9,62 \\
\hline P & & & & & & 10 & & 10 & 9,62 \\
\hline W & 4 & 4 & 4 & & & & 10 & 22 & 21,15 \\
\hline Score & 18 & 16 & 16 & 14 & 14 & 12 & 14 & 104 & 100,00 \\
\hline$\%$ & 17,31 & 15,38 & 15,38 & 13,46 & 13,46 & 11,54 & 13,46 & 100,00 & \\
\hline
\end{tabular}

\subsection{Waste Assessment Model}

A waste assessment questionnaire (WAQ) that consisted of 68 questions is used in this model to identify and allocate the production waste [16]. In WAQ, there are two types of question, i.e."from" which explained the type of waste that lead to other waste occurance and "to" which explained waste arising due to other waste. Each question consisted of three types of answer, i.e. "yes", "moderate", and "no" that have a point of $1,0,5$ and 0 . Product defect have the highest score at $24,45 \%$ as seen in Table 2 . Furthermore, the right of VALSAT is determined to analyze the prioritized production waste. Quality filter mapping (QFM) is VALSAT that can be used to analyze product defect.

Table 2. Waste assessment result

\begin{tabular}{|c|c|c|c|c|c|c|c|}
\hline & O & I & D & M & T & P & W \\
\hline Score $\left(\mathrm{Yj}_{\mathrm{j}}\right)$ & 0,46 & 0,47 & 0,53 & 0,63 & 0,63 & 0,74 & 0,47 \\
\hline Pj Factor & 0,02 & 0,03 & 0,04 & 0,01 & 0,01 & 0,01 & 0,03 \\
\hline Final result (Y final) & 0,01 & 0,01 & 0,02 & 0,01 & 0,01 & 0,01 & 0,01 \\
\hline Final result (\%) & 10,04 & 16,11 & 24,45 & 10,66 & 10,66 & 10,67 & 17,41 \\
\hline Rank & 7 & 3 & 1 & 6 & 5 & 4 & 2 \\
\hline
\end{tabular}




\subsection{VALSAT: Quality Filter Mapping (QFM)}

Quality filter mapping (QFM) is VALSAT that used to analyze product quality along the supply chain. The highest scrap deffect is in ngerok process at $15 \%$ level as seen in Figure 2. In this process, the wax in batik cloth is scrapped with a metal plate. This process is done manually, so it should be done carefully to minimize the defect.

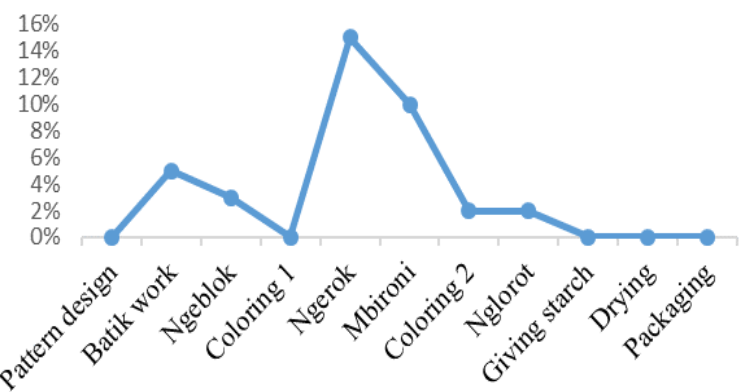

Figure 2. QFM of Batik CM

To identify the potential cause of product defect, a cause and effect analysis is conducted using fishbone diagram as seen in Figure 3. This diagram is a tool that can be used to identify possible causes of problems by listing all causes and effects [17]. The main cause of scrap defect in ngerok process is a low skill labor. To improve the product quality, a labor empowerment should be done by conducting training for the workers. This program is expected to be able to increase the labor skill in performing the job and reduce product defect.

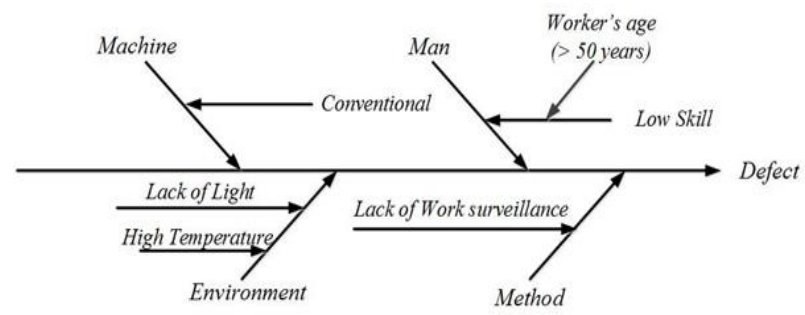

Figure 3. Fishbone diagram of defect in Ngerok process

\section{Conclussion}

Based on the research, the production process in Batik $\mathrm{CM}$ is dominated with a non value added activity at $50 \%$ from total lead time. The highest production waste occurs product defect at $23,08 \%$ from all production waste. This production waste becomes the main production waste that influence manufacturing performance of handwritten batik in Batik CM. The highest product defects rate is in ngerok process with $15 \%$ defect. Labor skill improvement by conducting a training should be done to minimize the product defects.

Researchers thank to the support of Industrial Engineering Department, Faculty of Industrial Technology, Universitas Islam Indonesia.

\section{References}

1. Urban, W., Organizational Culture Assessment as a Means of Lean Management Maturity Diagnosis, Journal of Management and Finance, Vol. 13, No. 4, 131-139, (2015)

2. Ministry of Industry, Jumlah Unit Usaha Batik 20112015, http://kemenperin.go.id/, Indonesia, (2015)

3. Murugunathan, V.R., Govindaraj, K, Sakhthimurugan, D., Process Planning Through Value Stream Mapping In Foundry, International Journal of Innovative Research in Science, Engineering and Technology, Vol.3, Issue 3, 11401143, (2014)

4. Motwani, J. A., Business Process Change Framework for Examining Lean Manufacturing: A Case Study, Industrial Management \& Data System, 339-346, (2003)

5. Indrawati, S. \& Ridwansyah, M., Manufacturing Performance Improvement Through Lean Six Sigma Method: An Iron Ores Industry Case Application, Procedia Manufacturing, Vol 4, 528-534, (2015)

6. Marshall, R.E., Farahbakhsh, K., Systems Approaches to Integrated Solid Waste Management in Developing Countries, Waste Management, Vol. 33, 988-1003, (2013)

7. Nordin, N., Osman, A.A., Adom, A.H., A Review on Lean Assessment Models and Performance Measures, Journal of Advanced Review on Scientific Research, Vol. 21, No.1., 1-26 (2016)

8. Wahaba, A.N.A., Mukhtara, M., Sulaiman, R., A Conceptual Model of Lean Manufacturing Dimensions, Procedia Technology, Vol. 11, 1292 1298, ( 2013 )

9. Manjunath, M., Shrivaprasad, H.C., Kumar, K.S.K, Puthran, D., Value Stream Mapping as a Tool for Lean Implementation: A Case Study, International Journal of Innovative Research \& Development, Vol. 3, Issue 5, 477-481, (2014)

10. Xia, W, Sun, J., Simulation Guided Value Stream Mapping and Lean Improvement: aCase Study of a Tubular Machining Facility, Journal of Industrial Engineering and Management, Vol. 6(2), 456-476, (2013)

11. Roother, M., \& Shoock, J., Learning to See Value Stream Mapping to Create Value and Eliminate Muda, Brookline, Massachusetts, USA, The Lean Enterprise Institute, (1998)

12. Voelkel, J., \& Chapman, C., Value Stream Mapping, Quality Progress, Vol.25, No.5 , 65-68, (2003)

13. Tjahjadi, B., Just-In-Time Purchasing, Just-In-Time Production System: Pengaruhnya Terhadap Kinerja Priduktifitas, Yogyakarta: Majalah Ekonomi, (2001)

14. Hines, Peter, \& Rich, Going Lean, Lean Enterprise Research Centre, Cardiff Business School, USA, (2000). 
15. Hines, P., \& Rich, N., The Seven Value Stream Mapping Tools, International Journal of Operation and Production Management, Vol. 17, (1997)

16. Rawabdeh, I. A., A Model for The Assessment of Waste in Job Shop Environments, Jordan: University of Jordan, (2005)

17. Wahid, A. N., Surachman, Setyanto, N. W., \& Soenoko, R., Implementasi Konsep Lean Manufacturing Untuk Meminimalkan Waktu Keterlambatan Penyelesaian Produk A Sebagai Value Pelanggan. Jurnal Rekayasa Mesin, Vol.4, No.2, 147-156, (2013) 